\title{
Diet composition and selection of the bighorn sheep (Ovis canadensis) in Sierra EI Mechudo, Baja California Sur, Mexico
}

Israel Guerrero-Cárdenas ${ }^{1,4}$, Sonia Gallina², Pablo Corcuera ${ }^{3}$, Sergio Álvarez-Cárdenas ${ }^{4 *}$ and Rafael Ramírez-Orduña ${ }^{5}$

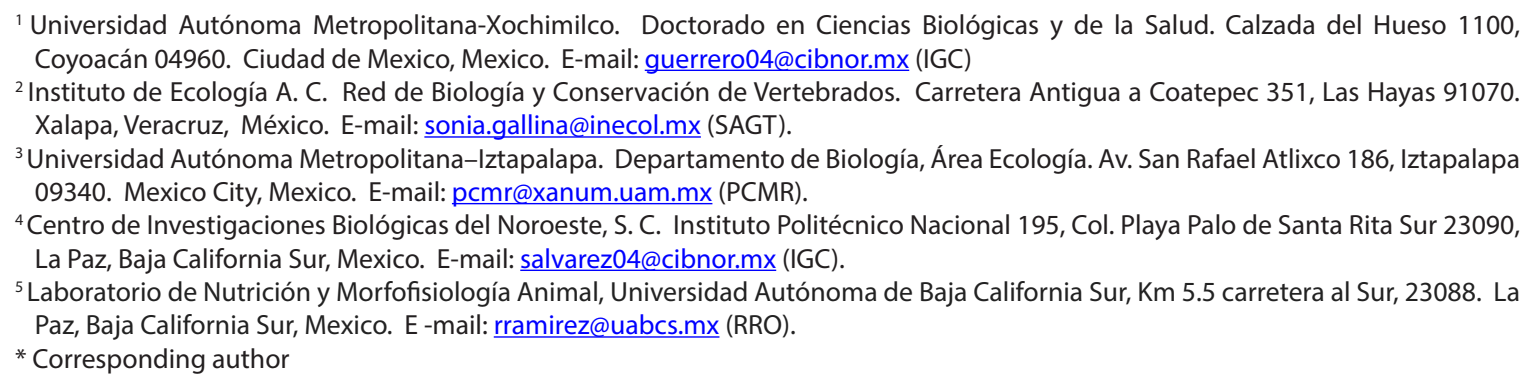

Water, food and nutrition are three of the main factors that regulate the distribution and abundance of wildlife species in a given area. In Baja California Sur, Mexico, the bighorn sheep is one of the most appreciated species for its ecological and economic value within the peninsular desert ecosystem; however, many aspects of its biology, ecology and population status remain unknown. The objective of the present study was to evaluate the diet composition of the bighorn sheep, analyzing the seasonal use and availability patterns of the plant species consumed. Using two food selection indices, we tested the hypothesis that the bighorn sheep opportunistically selects plant species from its habitat in the southern zone of Sierra El Mechudo, Baja California Sur, Mexico. The vegetation was characterized by means of 50 linear transects measuring $100 \mathrm{~m} \times 5 \mathrm{~m}\left(500 \mathrm{~m}^{2}\right)$. The diet of the bighorn sheep was evaluated through the microhistological analysis of feces. We calculated the percentage of in-vitro dry-matter digestibility and the digestible energy of forage consumed by sheep. The similarity of seasonal vs. annual diet was determined through a cluster analysis. From two food selection indices (Ivlev's electivity, Bonferroni), we estimated the proportion of use of plant species consumed by sheep to determine food preferences. In the habitat, we identified 21 families with 63 species in 2010 and 22 families with 50 species in 2011. Shrubs were the dominant forms. The analyses of faeces identified 47 species, consisting of 27 shrubs (62.1\%), 12 forbs ( $26.9 \%)$, six trees (10.6\%), one succulent $(0.2 \%)$ and one unidentified species (0.1\%). The cluster analysis showed seven similar groups. Ivlev's and Bonferroni indices showed the selection of Bourrieria sonorae, Melochia tomentosa and Caesalpinia placida by bighorn sheep in 2010; in 2011, it selected Bursera epinnata, Caesalpinia placida and Larrea tridentata. Non-significant differences between seasons were observed regarding the composition of plant species in the diet. Shrubs were the dominant life forms, followed by trees and succulents. Shrubs were the preferred food foraged by sheep, accounting for $62.1 \%$ of the diet; this finding is consistent with values reported for Arizona and California. Non-significant differences were observed in the percent in-vitro dry matter digestibility and digestible energy of the plant species foraged by sheep. However, we found that sheep grazed preferentially on four plant species, three shrubs and one tree, of high food quality. In this study, the bighorn sheep behaved like a specialist; therefore, we rejected the hypothesis that this species forages opportunistically on plant species. Studies on the diet of the bighorn sheep are valuable to develop management plans for the species and its habitat, since these provide information to better understand the extent of vegetation use and whether distribution sites are suitable and meet with the requirements for the conservation of the species and its populations.

Key words: Digestible energy; diversity; opportunistic; selection index; use-availability.

Para la fauna silvestre el agua, la alimentación y la nutrición son tres de los principales factores que regulan su distribución y el número de individuos de una especie en una área determinada. El borrego cimarrón en Baja California Sur, México, constituye una de las especies más apreciadas por su valor ecológico y económico dentro del ecosistema desértico peninsular, a pesar de esto, se desconocen muchos aspectos de su biología, ecología y situación poblacional. El objetivo del presente estudio fue evaluar la composición botánica de la dieta del borrego cimarrón, analizando los patrones de uso y disponibilidad de las especies vegetales estacionalmente. Usando dos índices de selección, probamos la hipótesis 
que el borrego cimarrón selecciona de manera oportunista las especies vegetales del hábitat, en la zona sur de la Sierra El Mechudo, Baja California Sur, México. Se caracterizó la vegetación por medio de 50 transectos lineales de 100 de largo por $5 \mathrm{~m}$ de ancho $\left(500 \mathrm{~m}^{2}\right)$. Se evaluó la dieta de los borregos, mediante la técnica microhistológica de las heces. Calculamos el porcentaje de digestibilidad In Vitro de la materia seca y la energía digestible de los forrajes consumidos por los borregos. Se determinó la similaridad de la dieta estacional y anualmente, a través de un análisis clúster. A partir de dos índices de selección (Ivlev, Bonferroni), calculamos la proporción de utilización de las especies vegetales que consumen los borregos para conocer las preferencias. Encontramos en el hábitat 21 familias con 63 especies en 2010 y 22 familias con 50 especies durante 2011. Las especies arbustivas fueron las formas dominantes. El análisis de excretas permitió identificar 47 especies, constituidas por 27 arbustos (62.1\%), 12 herbáceas (26.9 $\%)$, seis árboles (10.6\%), una suculenta (0.2\%) y una especie no identificada (0.1\%). El análisis clúster mostró siete agrupaciones similares. Los índices de Ivlev y de Bonferroni encontraron que en 2010 prefirieron a; Bourrieria sonorae, Melochia tomentosa y Caesalpinia placida. Mientras que para 2011, seleccionaron solo a Bursera epinnata, Caesalpinia placida y Larrea tridentata. No se observaron diferencias estadísticas por estación en la composición de especies de la vegetación, la cual fue escasa, apreciándose numerosas áreas con escasa cubierta vegetal. Las arbustivas son las especies dominantes, seguidas de los árboles y las suculentas. Las especies arbustivas fueron mayormente usadas por los borregos, constituyendo el $62.1 \%$ en toda la dieta, valores similares encontrados en Arizona y California. No se encontraron diferencias estadísticas en los valores de digestibilidad in vitro de la materia seca y de la energía digestible de las especies de plantas que consumen los borregos. Sin embargo, encontramos que los borregos seleccionaron cuatro especies, tres arbustos y un árbol, con valores altos de calidad. En este estudio, el borrego cimarrón se comportó como un especialista, por lo tanto rechazamos la hipótesis de que esta especie utiliza las especies vegetales de forma oportunista. Los estudios sobre la dieta de los borregos son valiosos para los planes de manejo de la especie y de su hábitat, ya que a partir de estos, podemos comprender el grado de utilización de la vegetación y saber si los sitios de distribución son adecuados y cumplen con los requerimientos necesarios para la conservación de la especie y sus poblaciones.

(c) 2016 Asociación Mexicana de Mastozoología, www.mastozoologiamexicana.org

\section{Introduction}

In desert areas, wild ungulates have developed effective strategies for the use of food resources, given the generally poor supply of high-quality resources; strategies are physiological (development of a digestive system that optimizes food processing) and behavioral (ability to select feeding grounds and food items; McNaughton 1986). In the particular case of the bighorn sheep, its large molars and digestive tract are an example of the physiological strategies allowing a better use and optimization of food resources (Rautenstrauch and Krausman 1989).

The factors that affect the quality of the diet in wild herbivores are: food intake (search, structural defenses of plants), accessibility to nutrients (digestibility, fiber content, among others), and concentration of secondary compounds in plants (Nagy and Haufler 1987; Nagy 1987). Two factors of the habitat with the strongest effect on the diet of wild ruminants are availability (quantity and accessibility) and quality of the plants consumed (nutritional content and digestibility; RamírezLozano 2004). Digestibility and digestible energy are considered to be key parameters that define the food quality of plants, and can vary significantly from one species to another due to climatic and seasonal factors (Di Marco 2011).

In nature we can distinguish two types of feeding strategies in wild animals. On the one hand, specialists have developed morphological and metabolic abilities to exploit resources not available for generalists. On the other, generalists have adapted their physiology to exploit various food items that are constantly available and can be temporarily abundant (Jacksic 1989; Laca and Demment 1996; Allen et al. 2011).

The desert subspecies of the bighorn sheep are opportunistic animals morphologically and physiologically adapted to graze, which can consume a large variety of plants, mainly grasses and forbs (Geist 1971; Cunningham 1989; DeYoung et al. 2000). However, due to the dominance of shrubs and trees in the Sonoran Desert, sheep graze mainly on these two life forms (Krausman et al. 1989). The bighorn sheep selects plant species with high protein content for maintenance and 
reproduction, as well as to cope with adverse weather conditions (Bailey et al. 1980). For sheep, food and nutrient intake are two of the main factors that regulate their distribution and abundance in a given area (Tarango and Krausman 1997).

The bighorn sheep (Ovis canadensis) is naturally distributed in the states of Baja California (O. C. cremnobates), Baja California Sur (O. c. weemsi) and Sonora (O. c. mexicana). The historical distribution of this species reveals that there were resident populations in the states of Chihuahua, Coahuila and Nuevo Leon (Valdez and Krausman 1999). Although in Baja California Sur, Mexico, the bighorn sheep is one of the most appreciated species for its ecological and economic value within the peninsular desert ecosystem, many aspects of its biology, ecology and population status still remain unknown.

During the past few years, several studies related to the bighorn sheep of Baja California Sur have focused on specific aspects of its particular habitat, including physical variables (Alvarez-Cárdenas et al. 2001), topography (Guerrero-Cárdenas et al. 2003), and structural elements (Alvarez-Cárdenas et al. 2009). However, some aspects related to food intake and nutrition are still unknown. The objective of the present study was to evaluate the diet composition of the bighorn sheep, analyzing the grazing patterns and seasonal availability of the plant species foraged. The testing hypothesis was that the bighorn sheep opportunistically selects some of the plant species in the habitat, taking as a study case the southern zone of Sierra El Mechudo, Baja California Sur, Mexico.

\section{Materials and Methods}

Study area. The study was carried out in the southern end of the Sierra El Mechudo, a mountainous area that borders the northern part of Bahía de La Paz, Baja California Sur. The site is known as El Junco, located within the ejido Ley Federal de Aguas Número Dos, $24^{\circ} 24^{\prime} 44.17^{\prime \prime} \mathrm{N}$ and $-110^{\circ} 45^{\prime}$ 9.10" W, covering an area of 117,578 ha (Figure 1).

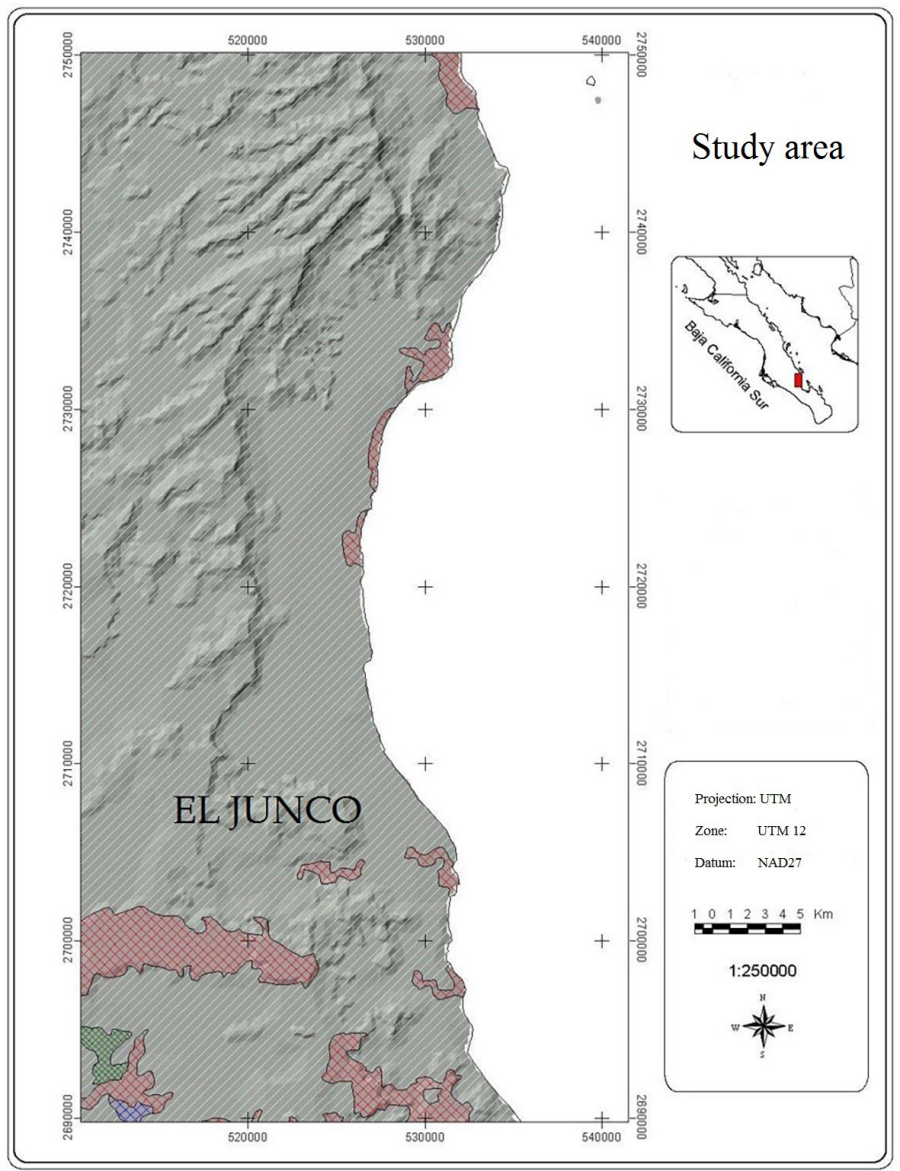

Figure 1. The study area known as Junco, comprises the southern part of the Sierra El Mechudo, $50 \mathrm{~km}$. north of the city of La Paz, Baja California Sur. 
Topographically, the area is formed by a mountain ridge running parallel to Bahía de La Paz, in the eastern coast of the peninsula, and comprises numerous canyons and cliffs. The study area shows three types of vegetation (Alvarez-Cárdenas et al. 2009): 1) thorny shrubs (species of deciduous trees and shrubs with prominent thorns), in the highest parts, with species such as Pachycormus discolor, Lemaireocereus thurberi and Opuntia sp.; 2) thornless shrubs (small-leaved scrubs with no thorns), in hillsides and canyons, dominated by Lysiloma candida, Ruellia californica and Fouquieria diguetii, and 3) thornless shrubs - cardon cacti (association of different thornless species and thorny succulent species), in the lowest parts, dominated by Pachycereus pringlei and Prosopis glandulosa.

The climate is warm, dry desert (García 1988), with mean annual temperature ranging between 22 and $35^{\circ} \mathrm{C}$, and mean monthly temperatures of 17.9 to $35.3^{\circ} \mathrm{C}$ in January and August, respectively. The rainfall regime is characterized by summer precipitation, which peaks in September (SARH 1983). Cyclical drought periods are common in the study area, and may last up to10 years (SARH 1983).

During the study, maximum temperatures of $45^{\circ} \mathrm{C}$ were recorded during the summer, with an average of $28^{\circ} \mathrm{C}$, with extremely scarce rainfall; this pattern occurred during the two years (Figure 2). Vegetation assessment. The vegetation (composition and structure) was evaluated each month using 50 linear transects measuring $100 \mathrm{~m} \times 5 \mathrm{~m}\left(500 \mathrm{~m}^{2}\right)$, according to the procedures by MuellerDombois and Ellenberg (1974) and Bonham (1989). The plant species were identified, recording the number of individuals, and coverage was measured (diameters and height of each individual). Samples of all plant species present in the sampling sites were collected to elaborate a reference catalog for the microhistological analyses (Peña and Habib 1980). Diversity was determined considering species richness and the number of individuals of each plant species in each transect using the Shannon-Wiener index (Magurran 1983).

Collection of feces and analysis of the diet. The plant composition of the sheep diet was determined annually (2010 and 2011) and seasonally (spring, summer, autumn and winter) using the microhistological technique, which identifies epidermis fragments of plants found in sheep feces based on the reference material (Sparks and Malechec 1968; Peña and Habib 1980). In each station, 30 to 40 fecal samples were collected monthly at random in sites where sheep were most active, as suggested by Anthony and Smith (1974).

From each group of fecal samples collected by station, five were chosen at random, and from this subgroup five slides of composite samples were prepared for each season of the year. A metallic slide with orifices of approximately $7 \mathrm{~mm}$ in diameter was used to maintain a homogeneous sample size. Subsequently, the species identified were classified according to order of importance (frequency of occurrence) in the diet, temporal variation and life form (shrub, tree, forb or grass and succulent). In each slide, 20 microscopic fields were observed at 100x magnification, identifying and quantifying the plant fragments observed. The cumulative frequency was obtained $\left(F=1-e^{-x}\right.$, where $F$ is frequency, $e$ is the base of natural logarithms, and $x$ is mean density), which was transformed to relative density for each season of the year (Peña and Habib 1980; Gallina 2012).

The percent contribution of each plant species was calculated. The species richness and diversity in the diet was calculated by season of the year through the Shannon-Wiener index (Magurran 1983; Moreno 2001). For each plant species found in sheep feces, the percentage of invitro dry matter digestibility (IVDMD; Caddel and Allen 2000; Schroeder 2012) using the following equation: \% IVDMD = 88.9 - (0.779*\% FDA), as well as the digestible energy content (DE = Mcal/ $\mathrm{kg} \mathrm{DM})$, using the formula suggested by Jurgen (2002) and Jones et al. (2010); DE $=4.618-0.0573$ (* FDA). Where Mcal = Mega calories per kilogram dry matter (dry matter is equal to plant weight minus its water content).

Statistical analysis. From a hierarchical analysis (cluster) of groups, the similarity of IVDMD and DE values was calculated for the plant species consumed by sheep each season. This analysis used the Pvclust R package (Suzuky 2014). 
$x^{2}$ tests were carried out to test for significant differences between years with respect to the plant species consumed by sheep, considering the richness of species consumed, percent relative density by species, percent IVDMD, and DE. These analyses were undertaken using the statistics program SPSS Statistic 0.20 (SPSS Inc., Chicago IL).

The selection of forage species by sheep was determined based on two analyses: First, Ivlev's electivity index (ISI; Strauss 1979), which relates in a simple way the proportion of each resource used and the proportion of the same resource in the habitat. ISI $=\left(r_{i}-n_{i}\right) /\left(r_{i}+n_{i}\right)$. Where: $r_{i}$ is the percentage of the species $i$ in the diet, and $n_{i}$ is the percentage of the species $i$ in the available vegetation. According to Stuth (1991), plant species were classified into three selectivity categories: preferred ( $>0.35$ ), proportional ( -0.35 to 0.35$)$ and avoided $(<-1.0)$. Second, from a $x^{2}$ goodnessof-fit test, which evaluated significant differences between expected use of each vegetation type (based on percent availability) and observed use (percent consumption). When the $x^{2}$ test shows differences between expected vs observed use, Bonferroni's confidence intervals are calculated (Byers et al 1984). These intervals were used to determine what plant species are being: a) selected, if the observed use is above the calculated interval (positive sign), b) avoided, if the observed use is below the calculated interval (negative sign), or (c) used according to availability, if the use observed falls within the estimated interval (equal sign; Marcum and Loftsgarden 1980; Byers et al. 1984).

\section{Results}

Vegetation. In the habitat, 21 Families with 63 species were identified in 2010, and 22 Families with 50 species in 2011. Shrubs were the dominant life forms, with heights of up to $1.90 \mathrm{~m}$ and a coverage of $1.20 \mathrm{~m}$. The Cactaceae and Euphorbiaceae were the best represented Families, with ten and eight species, respectively. At the same time, there were six trees, with a mean height of $2.9 \mathrm{~m}$, mainly represented by: Bursera microphyla, B. epinnata, Colubrina glabra, Lysiloma candida, Olneya tesota and Prosopis palmeri. A few forbs were found: six species in 2010 and three in 2011. The highest species abundance figures were recorded in autumn 2010 and winter 2011.

In the spring, summer and autumn 2010, the average richness was 45 species, which rose to 57 in winter. In summer and autumn 2011, 33 species were found, contrasting with only 24 in spring; however, species richness increased to 47 in winter. Annually, richness was 63 species in 2010: 31 shrubs (59.2\%), 12 trees (16.4\%), 12 succulents (13.6\%) and six forbs (10.8\%). Ruellia californica (12.0\%) and Jatropha cuneata (11.1\%) showed the largest number of individuals. In 2011, richness was 50 species: 22 shrubs $(61.0 \%), 14$ trees (17.3\%), 11 succulents $(17.0 \%)$, and three forbs (4.7\%); Jatropha cuneata (15.2\%) and Caesalpinia placida (10.0 \%) were the dominant shrubs and had the largest number of individuals. Diversity was minimum in spring $2011\left(\mathrm{H}^{\prime}=3.2\right)$ and maximum in winter $2010\left(\mathrm{H}^{\prime}=4.0\right)$. Evenness in the two years was $\mathrm{J}^{\prime}=0.85$.

Diet. The analysis of feces allowed the identification of 47 plant species in the two years of the study, composed mainly by 27 shrubs (62.1\%), 12 forbs (26.9\%), six trees (10.6\%), one succulent $(0.2 \%)$, and an unidentified species (0.1\%). Altogether, the shrubs Caelsalpinia placida (7.5\%), Melochia tomentosa (6.8\%) and Condalia globosa (5.7 \%) showed the highest relative density, followed by two grasses, Aristida adscencionis (9.5\%), and Bouteloua aristidoides (6.0\%).

Annually, sheep fed on 34 species of 21 Families in 2010: 21 shrubs (61.6\%), nine forbs (32.9 $\%)$ and four trees (5.5\%). The dominant species in the diet were Aristida adscencionis (12.2\%), Caelsalpinia. placida (7.7 \%), Condalia globosa (7.2\%), and Croton caboensis (6.2 \%). An increase was observed in 2011, with 39 species of 22 families: 23 shrubs (64.1\%), eight forbs $(21.3 \%)$, six trees $(14.2 \%)$, one succulent $(0.3 \%)$, and one unidentified species $(0.1 \%)$.

The grass A. adscencionis (7.8 \%) and the shrubs C. placida (7.4\%), Melochia tomentosa (7.1 $\%)$ and Larrea tridentata (6.1\%) were the species with the highest relative density. The trophic diversity showed no significant changes between years, with $\mathrm{H}^{\prime}$ values between 2.8 and 3.2 , and an evenness $J^{\prime}$ of 0.85 to 0.90 in the two years. 


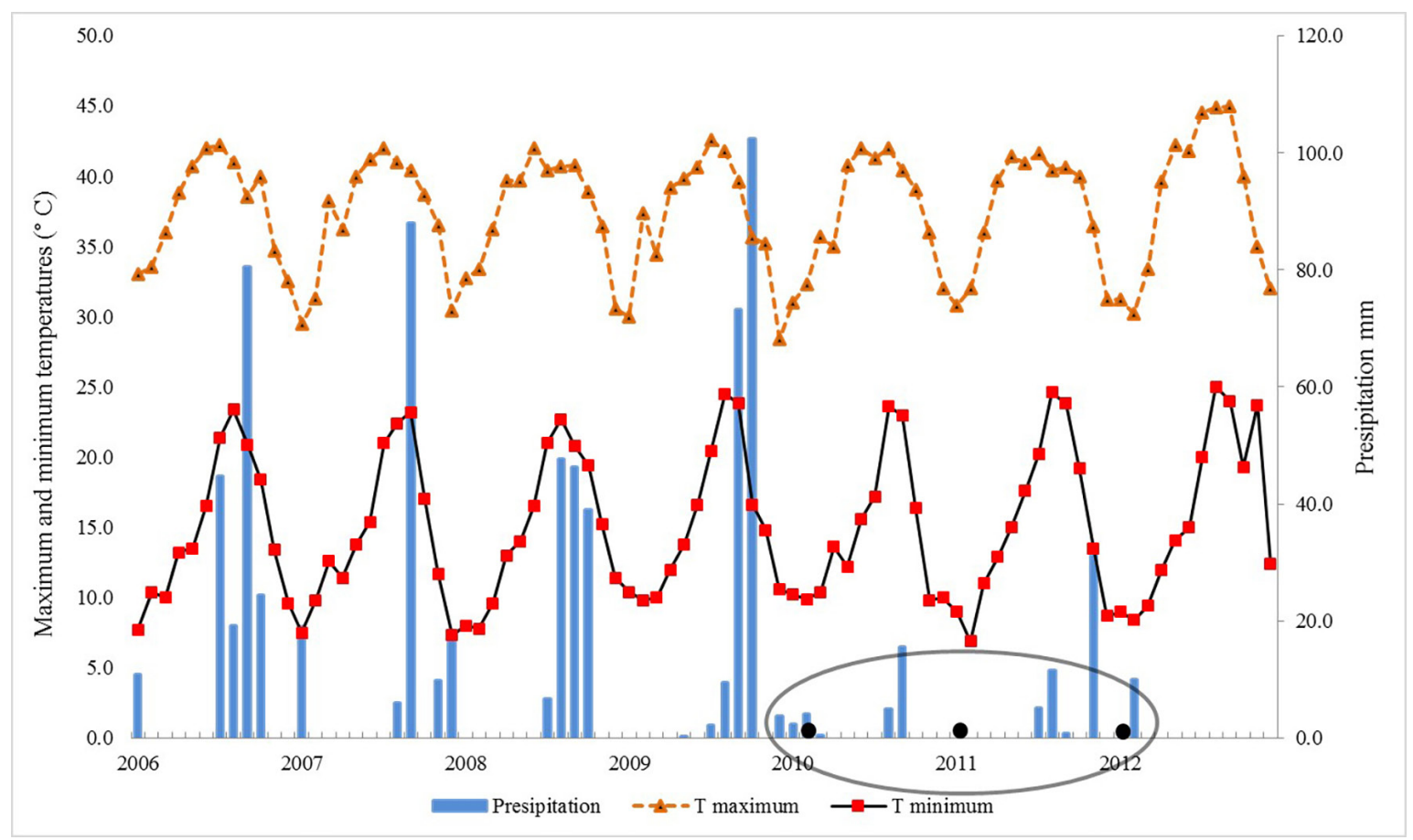

Figure 2. Temperature and precipitation values correspond to seven years of data (2006-2012) captured by the climate station Alfredo V. Bonfil (Comision Nacional del Agua) near the study area. The years of this study are from 2010 to 2011 as pointed out in the figure.

The cluster analysis (Figure 3) revealed seven groups at 95\% confidence, with the four seasons of 2010 forming the first four similar groups, while the remaining three correspond to spring, autumn and winter of 2011. Only the summer of 2011 showed different values in terms of number of individuals, IVDMD and DE, since the lowest values were recorded in this season.

The mean IVDMD in the two years was $68.2 \%$. Particularly in the winter 2010, the shrub Viscainoa geniculata showed the highest digestibility value, $71.8 \%$, while in summer and winter 2011 Opuntia cholla (succulent) obtained similar values, $71.6 \%$ in both cases. On average, the contribution of digestible energy during the two years was $2.40 \mathrm{Mcal} / \mathrm{kg} \mathrm{DM}$. Seasonally, in winter 2010 V. geniculata showed the highest value, $3.36 \mathrm{Mcal} / \mathrm{kg} \mathrm{DM}$, followed by the tree Lysiloma candida, with $3.21 \mathrm{Mcal} / \mathrm{kg}$ DM during spring. In summer, autumn and winter 2011, Fouquieria diguetii showed mean values of $3.15 \mathrm{Mcal} / \mathrm{kg} \mathrm{DM}$, while $O$. cholla showed values of $3.35 \mathrm{Mcal} / \mathrm{kg}$ DM only during the summer and winter, respectively.

The analysis of $x^{2}$ revealed significant differences between years with respect to the percent relative density $\left(x_{1,138}^{2}=221, p<0.0001\right)$ and number of plant species $\left(x^{2}{ }_{1,55}=96.512, p<0.0001\right)$, but not for IVDMD and $D E\left(x^{2}{ }_{1,190}=190.611, p=0.474\right.$; Table 1$)$.

Dietary Preferences. The Ivlev's electivity index identified seven species selected by sheep in the two years of study. In 2010 sheep selected mainly four shrubs: Bourrieria sonorae, Caesalpinia placida, Ditaxis sp. and Melochia tomentosa, with values above the 0.35 limit, while Ruellia califórnica and Hibiscus denodatus were observed in a proportion equal to their availability, with values below the range -0.35 to 0.35 . During 2011 sheep selected only one tree, Bursera epinnata, and two shrubs, C. placida and Larrea tridentata, while the shrubs Fouquieria diguetii and Jatropha cuneata were found in the diet in a proportion equal to their availability.

The Bonferroni analysis detected preferences for different species in the two years. In 2010 sheep selected two shrub species during the autumn; $B$. sonorae $\left(x^{2}=8.49, g . l .=3, p<0.05\right)$, and $M$. tomentosa $\left(x^{2}=197.94, g . l .=3, p<0.05\right)$; in the winter, sheep selected two shrubs and one forb; $C$. placida $\left(x^{2}=\right.$ $500.21, g . l .=3, p<0.05)$, R. californica $\left(x^{2}=3318.65, g . l .=3, p<0.05\right)$ e H. denudatus $\left(x^{2}=159.29, g . l .=\right.$ $3, p<0.05)$. In the spring 2011, sheep selected four shrubs and one tree; F. diguetii $\left(x^{2}=1245.18, g . l .=\right.$ $3, p<0.05)$ and L. tridentata $\left(x^{2}=268.82, g . I .=3, p<0.05\right)$, in summer J. cuneata $\left(x^{2}=4787.71, g . I .=3\right.$, 
$p<0.05)$, in autumn only C. placida $\left(x^{2}=1642.68, g . l .=3, p<0.05\right)$ and in the winter sheep selected $L$. tridentata again and B. epinnata $\left(x^{2}=78.71\right.$, g. I. $=3, p<0.05$; Table 2$)$.

\section{Discussion}

Vegetation. The results of this study showed a minimum variation of the species found each year, although a higher diversity was observed in 2011 vs. 2010. In contrast, the number of species was higher during 2010; this was likely influenced by the lack of precipitation during this study (Figure 2), indicating a prolonged drought, which in general affected the entire state of Baja California Sur, and probably was a determining factor in the distribution and abundance of vegetation. Hansen (1980) points out that the low rainfall in the deserts of North America leads to an unpredictable distribution of vegetation in general.

Table 1. Specific composition and percentage of relative density of forage species that make up the diet of bighorn sheep in the Junco area during 2010 and 2011. Only plant species that were found with values of greater than $2 \%$ in the excreta were recorded. Within the parenthesis, the value of percentage relative density of the species in the study area is indicated. Species without values in parentheses are species that did not appear in the transects.

\begin{tabular}{|c|c|c|c|c|}
\hline \multirow[t]{2}{*}{ Station } & \multirow[t]{2}{*}{ Life form } & \multirow[t]{2}{*}{ Species } & 2010 & \multirow[t]{2}{*}{2011} \\
\hline & & & $(\%)$ & \\
\hline \multirow[t]{14}{*}{ Spring } & Forbs & Abutilon sp. & 10.9 & 0 \\
\hline & & Aristida adscencionis & 13.4 & 14.1 \\
\hline & & Bouteloua aristidoides & 16.1 & 0 \\
\hline & Shrubs & Aeschinomene nivea & $0(5.1)$ & $10.1(5.6)$ \\
\hline & & Caelsalpinia placida & $0(0.6)$ & $5.3(27.5)$ \\
\hline & & Celtis reticulata & $4.6(1.9)$ & 0 \\
\hline & & Condalia globosa & 9 & 8.8 \\
\hline & & Croton caboensis & 12.9 & 0 \\
\hline & & Fouquieria diguetii & $0(10.1)$ & $7.3(8.3)$ \\
\hline & & Ditaxis $\mathrm{sp}$ & $4.2(0.2)$ & 0 \\
\hline & & Larrea tridentata & $0(4.1)$ & $11.8(1.2)$ \\
\hline & & Melochia tomentosa & $0(0.5)$ & $11.4(0.2)$ \\
\hline & & Ruellia californica & $3.6(13.4)$ & 0 \\
\hline & Trees & Bursera epinnata & 4.8 & 0 \\
\hline \multirow[t]{15}{*}{ Summer } & Forbs & Abutilon sp. & $10.8(0.7)$ & 0 \\
\hline & & Aristida adscencionis & 13.4 & 14.2 \\
\hline & & Bouteloua aristidoides & 16.1 & 11.6 \\
\hline & & Senna confinis & 0 & 3.7 \\
\hline & Shrubs & Celtis reticulata & 4.6 & 0 \\
\hline & & Condalia globosa & 0 & 6.7 \\
\hline & & Croton caboensis & 12.9 & 0 \\
\hline & & Croton magdalenae & 0 & 10.8 \\
\hline & & Ditaxis $\mathrm{sp}$ & $4.2(0.2)$ & 0 \\
\hline & & Euphorbia californica & 0 & 3.7 \\
\hline & & Fouquieria diguetii & $0(5.0)$ & $3.4(7.6)$ \\
\hline & & Haploppapus sonorensis & 0 & 8.1 \\
\hline & & Jatropha cuneata & $0(11.5)$ & $6.7(10.1)$ \\
\hline & & Ruellia californica & $3.6(13.4)$ & 0 \\
\hline & Trees & Bursera odorata & 0 & 3.4 \\
\hline \multirow[t]{3}{*}{ Autum } & Forbs & Aristida adscencionis & 10.2 & 5.9 \\
\hline & & Heteropongo contortus & 4.7 & 3.7 \\
\hline & & Janusia californica & 3.9 & 0 \\
\hline
\end{tabular}


Table1 (Cont'd).

\begin{tabular}{|c|c|c|c|c|}
\hline \multirow[t]{2}{*}{ Station } & \multirow[t]{2}{*}{ Life form } & \multirow[t]{2}{*}{ Species } & 2010 & 2011 \\
\hline & & & \multicolumn{2}{|c|}{$(\%)$} \\
\hline & Shrubs & Bourrieria sonorae & $6.7(0.4)$ & 0 \\
\hline & & Caesalpinia placida & $19.0(4.0)$ & $21.4(9.4)$ \\
\hline & & Calliandra californica & $0(0.9)$ & 4 \\
\hline & & Celtis reticulata & $7.5(1.6)$ & 0 \\
\hline & & Condalia globosa & 4.3 & 3.2 \\
\hline & & Ditaxis sp & $5.5(0.3)$ & 0 \\
\hline & & Jatropha cuneata & $0(7.7)$ & $4.5(16.9)$ \\
\hline & & Krameria parvifolia & 5.9 & $6.2(1.5)$ \\
\hline & & Melochia tomentosa & $11.1(0.5)$ & 10.5 \\
\hline & & Simonsia chinensis & $0(1.0)$ & $6.5(0.2)$ \\
\hline & & Vizcainoa geniculata & 0 & 4 \\
\hline & Trees & Bursera epinnata & $3.6(3.0)$ & $5.1(2.3)$ \\
\hline & & Bursera odorata & $3.9(0.7)$ & 4.2 \\
\hline \multirow[t]{21}{*}{ Winter } & Forbs & Aristida adscencionis & 14.5 & 0 \\
\hline & & Bouteloua aristidoides & 5.0 & 3.4 \\
\hline & & Heteropogon contortus & 8.1 & 3.9 \\
\hline & & Hibiscus denudatus & $3.0(2.8)$ & $4.8(5.5)$ \\
\hline & & Janusia californica & 10.0 & 0 \\
\hline & Shrubs & Aeschinomene nivea & $0(4.7)$ & $6.2(0.4)$ \\
\hline & & Buddleia corrugata & 0 & 3.4 \\
\hline & & Caesalpinia placida & $9.0(2.3)$ & $5.6(6.9)$ \\
\hline & & Celtis reticulata & 9.5 & 0 \\
\hline & & Condalia globosa & 6.3 & 0 \\
\hline & & Ditaxis sp & $5.5(0.3)$ & 0 \\
\hline & & Euphorbia californica & 0 & 6.2 \\
\hline & & Jatropha cuneata & $0(12.4)$ & $3.2(16.6)$ \\
\hline & & Krameria parvifolia & $0(0.3)$ & 3.2 \\
\hline & & Larrea tridentata & $0(2.8)$ & $8.4(1.6)$ \\
\hline & & Melochia tomentosa & $8.5(1.6)$ & $5(0.1)$ \\
\hline & & Ruellia californica & $6.7(12.4)$ & 7.7 \\
\hline & Trees & Bursera epinnata & $0(1.0)$ & $4.2(0.7)$ \\
\hline & & Colubrina glabra & $0(0.6)$ & 6.2 \\
\hline & & Lysiloma candida & $0(1.9)$ & $6.2(0.4)$ \\
\hline & & Olneya tesota & $0(0.1)$ & $4.5(1.9)$ \\
\hline
\end{tabular}

During the study, the plant cover observed was dry and decaying, and open sites devoid of vegetation were observed. Similar results were found in southern Arizona, when studying the diet of the mule deer in natural and rural areas. In Arizona, high temperatures and lack of rain were recorded, factors that directly affected the metabolism of plants, drying them up over a short period of time (Alcala-Galvan and Krausman 2012). In addition, these authors claim that rainfall directly affects the availability and quality of vegetation. Another important event associated with the lack of rainfall was the scarce presence and proliferation of grasses and herbaceous species, so that the higher abundance of species recorded in our study corresponded to shrubs, which dominate in the study area and in general across Sierra El Mechudo. Then, the evaluation of vegetation in the habitat where the bighorn sheep is distributed, along with plant composition and cover, are two useful parameters to predict areas of importance as feeding and shelter grounds (Hansen 1980). 
Diet. The diet of sheep in the two years of study included 47 plant species, mainly shrubs (62.1 $\%)$, followed by forbs (26.9\%) and trees (10.6\%). Similar results were recorded in the Sonoran Desert, with shrubs achieving the highest consumption ( $47.5 \%)$, followed by forbs and succulents (Tarango et al. (2002).

A study conducted in the northern peninsula of Baja California reports that the diet of sheep consisted of $43 \%$ grasses, $33 \%$ shrubs (including cacti) and $24 \%$ forbs (Sánchez 1976). In the same year, but in the southern part of the peninsula, the same author mentions that sheep consumed $53 \%$ grass, $23 \%$ shrubs, $17 \%$ forbs and $7 \%$ unidentified matter. The type of vegetation and

Table 2. Selection values (Ivlev's and Bonferroni) of plant species consumed by the bighorn sheep. The selectivity index (Ivlev's) was interpreted into three categories: preferred $(S)(>0.35)$, proportional $(P)(-0.35$ to 0.35$)$ and avoided (E) (-1.0). Bonferroni intervals show which plant species are being selected, avoided or used according to their availability in the environment; selection (+), avoided (-) and use according to their availability (=). Expected Use $=\mathrm{EU}$, Observed Use = OU, Lower Limit= LL, Upper Limit $=$ UL.

\begin{tabular}{|c|c|c|c|c|c|c|c|}
\hline \multicolumn{8}{|c|}{2010} \\
\hline Species & $\mathbf{E U}$ & OU & $\mathbf{L L}$ & UL & Type of use & IVLEV & Type of use \\
\hline \multicolumn{8}{|c|}{ Bourrieria sonorae } \\
\hline spring & 0.290 & 0.273 & -0.486 & 0.058 & $=$ & 0.47 & $\mathbf{S}$ \\
\hline summer & 0.258 & 0.273 & -0.187 & 0.330 & $=$ & 0.41 & $\mathbf{S}$ \\
\hline autumn & 0.194 & 0.409 & -0.370 & 0.156 & + & 0.88 & $\mathbf{S}$ \\
\hline winter & 0.258 & 0.045 & 0.043 & 0.457 & - & -0.30 & $\mathbf{P}$ \\
\hline \multicolumn{8}{|c|}{$\chi^{2}=8.49$ g.l. $=3 \mathrm{p}<0.05$} \\
\hline \multicolumn{8}{|c|}{ Caesalpinia placida } \\
\hline spring & 0.058 & 0.078 & -0.103 & 0.063 & $=$ & 0.57 & $\mathbf{S}$ \\
\hline summer & 0.273 & 0.078 & 0.081 & 0.308 & - & -0.26 & $\mathbf{P}$ \\
\hline autumn & 0.446 & 0.558 & -0.274 & 0.050 & $=$ & 0.65 & $\mathbf{S}$ \\
\hline winter & 0.223 & 0.286 & -0.206 & 0.081 & + & 0.59 & $\mathbf{S}$ \\
\hline \multicolumn{8}{|c|}{$\chi^{2}=500.21$ g.l. $=3 \mathrm{p}<0.05$} \\
\hline \multicolumn{8}{|c|}{ Ditaxis. $S p$} \\
\hline spring & 0.182 & 0.216 & -0.325 & 0.257 & $=$ & 0.91 & $\mathbf{S}$ \\
\hline summer & 0.182 & 0.216 & -0.325 & 0.257 & $=$ & 0.90 & $\mathbf{S}$ \\
\hline autumn & 0.364 & 0.294 & -0.285 & 0.424 & - & 0.90 & $\mathbf{S}$ \\
\hline winter & 0.273 & 0.275 & -0.334 & 0.330 & $=$ & 0.91 & $\mathbf{S}$ \\
\hline \multicolumn{8}{|c|}{$\chi^{2}=8.10$ g.1. $=3 p<0.05$} \\
\hline \multicolumn{8}{|c|}{ Hibiscus denudatus } \\
\hline spring & 0.293 & 0.182 & -0.090 & 0.313 & - & -0.45 & $\mathbf{P}$ \\
\hline summer & 0.185 & 0.182 & -0.194 & 0.200 & $=$ & -0.39 & $\mathbf{P}$ \\
\hline autumn & 0.312 & 0.273 & -0.189 & 0.268 & - & -0.27 & $\mathbf{E}$ \\
\hline winter & 0.210 & 0.364 & -0.394 & 0.088 & + & 0.04 & $\mathbf{P}$ \\
\hline \multicolumn{8}{|c|}{$\chi^{2}=159.29$ g.l. $=3 p<0.05$} \\
\hline \multicolumn{8}{|c|}{ Melochia tomentosa } \\
\hline spring & 0.111 & 0.111 & -0.131 & 0.131 & $=$ & 0.68 & $\mathbf{S}$ \\
\hline summer & 0.407 & 0.111 & 0.122 & 0.470 & - & 0.01 & $\mathbf{E}$ \\
\hline autumn & 0.130 & 0.444 & -0.488 & -0.141 & + & 0.91 & $\mathbf{S}$ \\
\hline winter & 0.352 & 0.333 & -0.179 & 0.216 & $=$ & 0.68 & $\mathbf{S}$ \\
\hline \multicolumn{8}{|c|}{$\chi^{2}=197.94$ g.l. $=3 \mathrm{p}<0.05$} \\
\hline \multicolumn{8}{|c|}{ Ruellia californica } \\
\hline spring & 0.299 & 0.220 & -0.072 & 0.232 & - & -0.58 & $\mathbf{P}$ \\
\hline summer & 0.182 & 0.220 & -0.187 & 0.113 & $=$ & -0.51 & $\mathbf{P}$ \\
\hline autumn & 0.236 & 0.146 & -0.041 & 0.220 & - & -0.62 & $\mathbf{P}$ \\
\hline winter & 0.282 & 0.415 & -0.310 & 0.045 & + & -0.30 & $\mathbf{E}$ \\
\hline$\chi^{2}=$ & 0.05 & & & & & & \\
\hline
\end{tabular}


Table 2 (Cont'd).

\begin{tabular}{|c|c|c|c|c|c|c|c|}
\hline \multicolumn{8}{|c|}{2011} \\
\hline Species & UE & UO & LI & $\mathbf{L S}$ & Type of use & IVLEV & Type of use \\
\hline \multicolumn{8}{|c|}{ Bursera epinnata } \\
\hline spring & 0.350 & 0.048 & -0.451 & -0.140 & - & 0.86 & $\mathbf{S}$ \\
\hline summer & 0.283 & 0.071 & 0.182 & 0.549 & - & -0.52 & $\mathbf{P}$ \\
\hline autumn & 0.250 & 0.476 & -0.178 & 0.254 & $=$ & 0.37 & $\mathbf{S}$ \\
\hline winter & 0.117 & 0.405 & -0.292 & 0.076 & + & 0.73 & $\mathbf{S}$ \\
\hline \multicolumn{8}{|c|}{$\chi^{2}=78.71$ g.l. $=3 p<0.05$} \\
\hline \multicolumn{8}{|c|}{ Caelsalpinia placida } \\
\hline spring & 0.532 & 0.205 & 0.219 & 0.435 & - & -0.68 & $\mathbf{P}$ \\
\hline summer & 0.010 & 0.054 & -0.093 & 0.006 & $=$ & 0.57 & $\mathbf{S}$ \\
\hline autumn & 0.208 & 0.545 & -0.454 & -0.218 & + & 0.39 & $\mathbf{S}$ \\
\hline winter & 0.249 & 0.196 & -0.049 & 0.154 & - & -0.10 & $\mathbf{P}$ \\
\hline \multicolumn{8}{|c|}{$\chi^{2}=1642.68$ g.l. $=3 p<0.05$} \\
\hline \multicolumn{8}{|c|}{ Fouquieria diguetii } \\
\hline spring & 0.132 & 0.610 & -0.463 & -0.153 & + & -0.07 & $\mathbf{P}$ \\
\hline summer & 0.219 & 0.156 & -0.125 & 0.133 & - & -0.38 & $\mathbf{P}$ \\
\hline autumn & 0.241 & 0.117 & -0.045 & 0.194 & $=$ & -0.58 & $\mathbf{P}$ \\
\hline winter & 0.408 & 0.117 & 0.105 & 0.354 & - & -0.59 & $\mathbf{P}$ \\
\hline \multicolumn{8}{|c|}{$\chi^{2}=1245.18$ g.l. $=3 \mathrm{p}<0.05$} \\
\hline \multicolumn{8}{|c|}{ Jatropha cuneata } \\
\hline spring & 0.128 & 0.131 & -0.106 & 0.100 & $=$ & -0.71 & $\mathbf{P}$ \\
\hline summer & 0.229 & 0.361 & -0.277 & 0.013 & + & -0.40 & $\mathbf{P}$ \\
\hline autumn & 0.247 & 0.295 & -0.187 & 0.090 & $=$ & -0.58 & $\mathbf{P}$ \\
\hline winter & 0.397 & 0.213 & 0.055 & 0.312 & - & -0.68 & $\mathbf{P}$ \\
\hline \multicolumn{8}{|c|}{$\chi^{2}=4787.71$ g.l. $=3 \mathrm{p}<0.05$} \\
\hline \multicolumn{8}{|c|}{ Larrea tridentata } \\
\hline spring & 0.084 & 0.478 & -0.529 & -0.259 & + & 0.81 & $\mathbf{S}$ \\
\hline summer & 0.313 & 0.065 & 0.120 & 0.376 & - & -0.41 & $\mathbf{P}$ \\
\hline autumn & 0.398 & 0.120 & 0.136 & 0.420 & - & -0.32 & $\mathbf{P}$ \\
\hline winter & 0.205 & 0.337 & -0.281 & 0.016 & + & 0.68 & $\mathbf{S}$ \\
\hline \multicolumn{8}{|c|}{$\chi^{2}=268.82$ g. $1 .=3 p<0.05$} \\
\hline
\end{tabular}

climate in the latter study are similar to those in our study area. Investigations on the diet of sheep in the Rocky Mountains, in the northern part of the U. S. A., found similar results, where grasses and forbs dominate the preferred plant species eaten (Brown et al. 1977; Seegmiller and Ohmart 1981). This contrasts with our results, where only two grass species were present in the diet of the bighorn sheep in all seasons and in smaller proportion than shrubs.

The desert bighorn sheep eats an average of up to 110 plant species in arid zones during two or three years (Browning and Monson 1980). While in areas of northern United States and southern Canada, the Rocky Mountain sheep feeds on up to 200 plant species (Brown et al. 1977; Seegmiller and Ohmart 1981); in Arizona, 58 species (Krausman et al. 1989); in California, 32 species (Seegmiller and Ohmar (1981); and in Sonora, Mexico, 41 species (Tarango et al. (2002); the latter results are similar to those found in our study, with 34 to 39 plant species eaten per year.

Shrubs were the life forms with the highest frequency in the diet during the two years of the study. The reason for the preference for shrubs in this study partly lies in the fact that these are perennial plants and represent food items that are available throughout the year. In addition, wild 


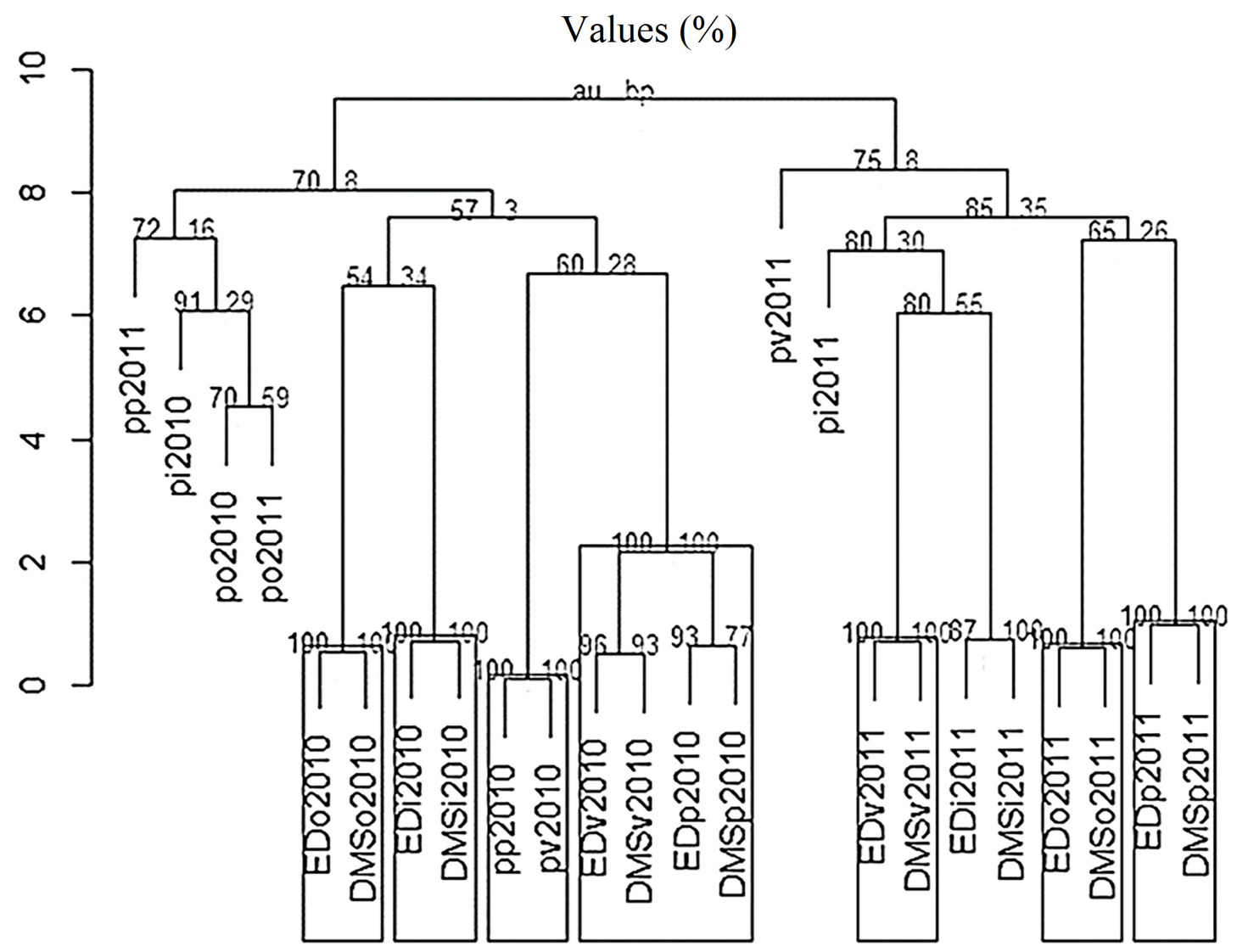

Euclidean distance

Pvrect (result, alpha $=0.95$ )

Figure 3. Cluster grouping analysis (dendrogram) showing seasonal similarity according to the values of in vitro digestibility of dry matter (IVDDM) and digestibility energy (DE) in each of the plant species consumed by sheep. Larger clusters stand out as rectangles with $95 \%$ significance levels.

ungulates consume more shrubs and trees in spring and summer because these life forms contain more digestible nutrients, which become available as buds start to grow (Bolen and Robinson 2002; McNaughton 1986).

With regard to the seasonal diet, the summer 2011 showed the greatest contribution of species consumed ( $n=32$ ), coinciding with the study by Brewer and Harverson (2007) on sheep in the Texas desert. The authors state that the highest consumption occurs in the summer and remains until the end of the autumn under normal rainfall conditions.

In general during all seasons, a similar contribution of plant species was observed, with a slight variation between seasons, and plant diversity was relatively constant throughout the years, with 2.8 in 2010 and 3.3 in 2011. This contrasts with the findings reported by Tarango et al. (2002), where the mean diversity in the diet varied between 0.47 and 0.51 , considered as a low value by the authors, that was attributed to the lack of rainfall during their study.

In the present study, low values were found in the consumption of plant species in autumn, and although the weather conditions were not particularly harsh $\left(32\right.$ to $\left.36^{\circ} \mathrm{C}\right)$, plants began to dry up, becoming less palatable for sheep. However, the number of species consumed increased in winter, likely because weather improves significantly in this season (temperature decreases from $45^{\circ} \mathrm{C}$ to $30^{\circ} \mathrm{C}$ ), representing better conditions for sheep. This situation induces sheep to move about for longer periods, hence consuming a higher number of plant species and seek individual species (Brewer and Harverson 2007). 
Dietary Preferences. In our study, not all plant species were consumed in proportion to their availability, since we found differences between availability and consumption of plant species. In 2010, sheep fed on 17 species out of the 63 that were recorded. In 2011, the number of species consumed remained unchanged (17) out of 50 species available. These results may be due to the fact that the evaluation of the vegetation failed to include all species, given the great extension of the study area, and to the fact that during the collection of feces it was impossible to access some sites where sheep were observed due to the difficult terrain.

The differences in the diet of sheep are also attributable to the movements during the day, since animals cover a distance of up to $20 \mathrm{~km}$ in a single day (Cuninham and Ohmart 1986). During these movements, animals feed in different sites on a variety of plant species and life forms. In addition to the likely explanations just mentioned, sheep used the different types of food not necessarily according of their availability; this consumption pattern may also be associated with certain characteristics of the plants eaten, such as digestibility, variety of nutrient content, palatability and texture (Krausman et al. 1989).

Bailey (1980); Browning and Monson (1980); Krasuman et al. (1989) pointed out that the adaptations of the desert sheep have enabled it to colonize and survive in sites with relatively scarce vegetation. This suggests that sheep has no preference for any particular type and feeds on whatever food types are available; for this reason, the bighorn sheep has been considered to be an opportunist. However, our analysis of food selection indicated that sheep do select at least three plant species each year of study, according to the two indices used (Bonferroni and Ivlev). These plant species have acceptable digestibility values, a likely explanation of their being preferred. The above is consistent with the results reported by Martinez (2010), who mentions that the selectivity of certain types of food by wild ungulates is related to the energy and nutritional requirements according to the physiological status of the animals.

In this study, it was found that sheep selected Caesalpinia placida and Melochia tomentosa during the autumn 2010 and winter 2011, but preferred Larrea tridentata in winter and spring 2011. These species show good-quality digestibility values, according to figures reported by Caddel and Allen (2000); Di Marco (2011); Schroeder (2012) and Minson (1990), who indicate that plant species of good forage quality for wild ruminants must have an IVDMD value of $50 \%$; alternatively, they consider that a high-quality forage have an IVDMD value of approximately 70 $\%$; by contrast, forage types with IVDMD values below 50 are considered to be low-quality food.

Furthermore, the selection of those species may be due to that at least two of them (C. placida and L. tridentata) were found with the highest abundance, being dominant species in the area. On the other hand Croton caboensis, Lysiloma candida and Viscainoa geniculata were the species with the greatest contributions in terms of digestible energy in all seasons, with 3.1 to $3.3 \mathrm{Mcal} / \mathrm{kg}$ $\mathrm{DM}$, and although these were not preferentially selected, were consumed in a proportion equal to their availability. This may be due to the fact that the bighorn mating season takes place in summer and autumn, leading to the first births in winter, which induces animals to feed on plant species with high digestibility values that provide energy during these periods.

In general, digestible energy was low relative to forage consumed by sheep in the Rocky Mountains in northern USA (2.12-2.80 Mcal/kg DM vs. 10.4-8.70 Mcal/kg DM, respectively; Shank 1982). On the other hand, the digestibility of forage consumed by sheep in California varied from $33.4 \%$ to $38.7 \%$ and $21.5 \%$ to $75.3 \%$ within a single year (Rominger et al. 1988; Rominger et al. 1988). The proportion of the grass Aristida adecencionis was higher (66.8\%) in the winter, while the shrub Atriplex hymenelytra reached levels of $69.9 \%$ to $75.3 \%$ in all seasons. These food types are of good quality for sheep, as they meet its daily energy requirement.

The digestible energy of the different plant species consumed by the white tail deer in Nuevo Leon is obtained throughout the different seasons of the year, with the lowest intake in the summer (1.99 Mcal/kg DM) and peak values in winter (2.15 Mcal/kg DM; Ramírez-Lozano 2004), 
which are sufficient to fulfill the maintenance requirements of deers. In our study, the digestible energy levels recorded are consistent with those reported in study on deer, ranging from 1.61 to $2.45 \mathrm{Mcal} / \mathrm{kg} \mathrm{DM}$, which fulfill at least the energy requirements for the daily maintenance of the bighorn sheep throughout the year.

In this study, the bighorn sheep behaved as a specialist. Therefore, we rejected the hypothesis that sheep consume plant species opportunistically. This is due to the finding that sheep did not feed on the various plant species in proportion to their availability. It was noted that as the availability of forage with high digestibility and digestible energy decreases (mainly shrubs), the bighorn sheep incorporates other available species into its diet in spite of their lower IVDMD and DE levels.

The plant species selected as food items by sheep in its diet may vary in the different seasons, depending on their availability and abundance. The bighorn sheep can behave either as a specialists or as a generalist, and environmental conditions usually determine the availability and consumption of food types (Martínez 2010).

The studies on the diet of the bighorn sheep are valuable for the development of management plans for this species and its habitat, since it allows to understand the degree of utilization of the vegetation and whether it fulfills the requirements for the survival of the bighorn sheep and their populations.

\section{Acknowledgments}

Field information was obtained thanks to the support of projects CONABIO GN024 and CIBNOR PC0.24 directed by S. Alvarez Cárdenas. We wish to thank the Chief of the Ejido Federal de Aguas No. 2 and the company Roca Fosfórica Mexicana for facilitating access to El Junco. We also thank the technicians F. Cota, A. Cota and M. Acevedo for their assistance in data recording during field work, as well as the persons who reviewed the manuscript, P. Peña, R. Garcia and C. Cornejo. To the PhD degree in Biological and Health Sciences, Universidad Autónoma Metropolitana; M. J Ferrara, H. Gonzales and M. A. Castillo. To D. Dorantes, for assistance in the translation of the abstract into English. To two anonymous reviewers and R. Reyna for their valuable comments, which contributed to improve the quality of this work. This manuscript was translated by Maria Elena Sánchez Salazar with support of THERYA through a CONACYT grant.

\section{Literature Cited}

Alcala-Guzman, H. C., and P. R. Krausman. 2012. Diets of desert mule deer in altered habitats in the lower Sonoran Desert. California Fish and Game 98:81-103.

Allen, V. G., C. Batello, E. J. Berretta, J. Hodgson, and M. Kothmann. 2011. An international terminology for grazing lands and grazing animals. Grass and Forage Science 66:2-28.

Álvarez-Cárdenas, S., I. Guerrero-Cárdenas, P. Galina-Tessaro, and S. Gallina. 2001. The variables of physical habitat selection by the desert bighorn sheep (Ovis canadensis weemsi) in the Sierra del Mechudo, Baja California Sur, Mexico. Journal of Arid Environments 49:357-374.

Álvarez-Cárdenas, S., P. Galina-Tessaro, S. Díaz-Castro, I. Guerrero-Cárdenas, A. Castellanos-Vera, and E. Mesa-Zavala. 2009. Evaluación de elementos estructurales del hábitat del borrego cimarrón en la Sierra del Mechudo, Baja California Sur, México. Tropical Conservation Science 2:189-203.

Anthony, R. G., And N. S. Smith. 1974. Comparison of rumen and fecal analysis to describe deer diets. Journal Wildlife Managements 30: 305-311.

Balley, J. A. 1980. Desert bighorn, forage competition and zoogeography. Wildlife Society Bulleting 12:208-2016.

Bleich, C. B., R. T. Bowyer, J. Deborah, T. O. Clark. 1992. An analysis of forage used by mountain sheep in the eastern Mojave Desert, California. Desert Bighorn Council Transactions 36:41-47. 
Bolen, E. G., And W. L. Robinson. 2002. Wildlife Ecology and Management. Edition: $5^{\text {th }}$. Prentice Hall Inc. Englewood Cliffs, U. S. A.

Bonham, CH. D. 1989. Measurements of terrestrial vegetation. John Wiley and Sons. New York, U. S. A.

Brewer, C. E., And L. A. Harverson. 2007. Diets of bighorn sheep in the Chihuahua desert. The Southwestern Naturalist 52:97-103.

Brown, R. W., D. D. Smith, ANd R. P. McQuivey. 1977. Food habits of desert bighorn sheep in Nevada, 1956-1976. Desert Bighorn Council Transactions 21:13-16.

Browning, B. M., AND G. Monson. 1980. Food. Pp. 80-92, in The Desert Bighorn Sheep: its life, history, ecology, and management (Monson, G., and L. Sumner, eds.). University of Arizona Press. Tucson, U. S. A.

Byers, C. R., R. K. Steinhorst, and P. R. Krausman. 1984. Clarification of a technique for analysis of utilization-availability data. Journal of Wildlife Management 48:1050-1053.

Caddel, J., And E. Allen. 2000. Forage Quality interpretations. Division of Agriculture Sciences and Natural Resources. Oklahoma University. Stillwater, U. S. A.

Cunningham, S., And R. Оhmart. 1986. Aspects of the ecology of desert bighorn sheep in Carrizo Canyon California. Desert Bighorn Council Transactions 30:14-19.

Cunningham, S. C. 1989. Evaluation of bighorn sheep habitat. Pp. 135-160, in The desert bighorn sheep in Arizona (Lee, R. M., ed.). Arizona Game and Fish Department. Phoenix, U. S. A.

DeYoung, W. R., E. C. Hellgren, T. E. Fulbright, W. F. Robbins Jro, and I. D. Humphreys. 2000. Modeling nutritional carrying capacity for translocated desert bighorn sheep in western Texas. Restoration Ecology 8:57-65.

Dı Marco, O. 2011. Estimación de la calidad de forrajes. Facultad de Ciencias Agrarias. Producir XXI 20:24-30.

Galuina, S. 2012. Técnicas para conocer la dieta. Pp. 217-234, in Manual de técnicas para el estudio de la fauna (Gallina-Tessaro, S., and C. López-González, eds.). Instituto de Ecología, A. C., Universidad Autónoma de Querétaro, INE-SEMARNAT. Ciudad de México, México.

García, E. 1988. Modificaciones al sistema de clasificación climática de Koeppen. Instituto de Geología, UNAM. Ciudad de México, México.

Geıst, V. 1971. Mountain Sheep: A Study in Behavior and Evolution. The University of Chicago Press. Chicago, U.S. A.

Guerrero-Cárdenas, I., I. Tovar-Zamora, and S. Álvarez-Cárdenas. 2003. Factores que afectan la distribución del borrego cimarrón Ovis canadensis weemsi en la Sierra del Mechudo, B. C. S., México. Anales del Instituto de Biología, Universidad Nacional Autónoma de México, Serie Zoología 74:83-98.

Hansen, C. G. 1980. Habitat evaluation. Pp. 320-335 in the desert bighorn sheep (Monson, G., and G. Sumner, eds.). University Arizona Press. Tucson, U. S. A.

JAKSIC, F. M. 1989. Opportunist, selective and other often-confused terms in the predation literature. Revista Chilena de Historia Natural 62:7-8.

Jones, P. D., K. B. Strickland, S. Demarais, B. J. Rude, S. L. Edwars, and P. James. 2010. Soils and forage quality as predictor of White-tailed deer Odocoileus virginianus morphometrics. Wildlife Biology 16:430-439.

Jurgens, M. H. 2002. Animal feeding and nutrition. 9th edition. Kendall/Hunt Publishing. Dubuke, U. S. A.

Krausman, P. R., B. D. Leopold., R. F. Seegmiller, and G. T. Steven. 1989. Relationships between desert bighorn sheep and habitat in western Arizona. Wildlife Monographs 53:66.

Laca, E. A., And M. W. Demment. 1996. Foraging strategies of grazing animals. Pp. 137-158, in The ecology and management of grazing systems (Hodgson, J., and A. W. Illius, eds.). CAB International. Wallingford, United Kindom.

MagurRan, A. E. 1983. Diversidad ecológica y su medición. Ed. Vendra. Barcelona, España.

Marcum, C. L., AND D. LoftsgaARden. 1980. A nonmapping technique for studying habitat preferences. Journal of Wildlife Management 44:963-968.

Martínez, T. 2010. Selección y estrategia alimentaria de los machos, hembras y jóvenes de cabra montés (Capra pirenaica Schinz, 1838) en el suroeste de España. Galemys 22: 483-515 
McNaughton, S. J. 1986. On plants and herbivores. American Naturalist 128:765-770.

Minson, D. J. 1990. Forage in ruminant nutrition. Academic Press, Inc. New York, U. S. A.

MoReNo, C. E. 2001. Métodos para determinar la biodiversidad. M\&T-Manuales y Tesis SEA. Zaragoza, España.

Mueller-Dombois, D., AND H. Ellenberg. 1974. Aims and methods of vegetation ecology. John Wiley and Sons. New York, U. S. A.

Nagy, J. G., AND J. B. Haufler. 1987. Nutrición de los animales silvestres. Pp. 135-149, in Manual de técnicas de gestión de vida silvestre (Rodríguez T., R., ed.). The Wild Life Society. Maryland, U. S. A.

NAGY, K. A. 1987. Field metabolic rate and food requirement scaling in mammals and birds. Ecological Monographs 57:111-128.

Peña, J. M., And R. P. Habib. 1980. La técnica microhistologica. Un método para determinar la dieta la composición botánica de la dieta de herbívoros. Instituto Nacional de Investigaciones Pecuarias. Departamento de Manejo de Pastizales. Serie Técnico Científica I:80.

Ramírez-Lozano, R. G. 2004. Nutrición del venado cola blanca. Publicaciones Universidad Autónoma de Nuevo León. San Nicolás de Los Garza, México.

Rautenstrauch, K. R., and P. R. Krausman. 1989. Influence of water availability and rainfall on movements of desert mule deer. Journal of Mammalogy 70:197-201.

Rominger, E. M., A. R. Dale, and J. A. Bailey. 1988. Shrubs in the summer diet of rocky mountain bighorn sheep. Journal of Wildlife Management 52:47-50.

Sanchez, D. R. 1976. Analysis of stomach contents of bighorn sheep in Baja California. Desert Bighorn Council Transactions 20:21-22.

SARH. 1983. Baja California Sur. Carta Sinóptica. Escala 1:50 000. Carta No. 2. Secretaría de Agricultura y Recursos Hidráulicos.

ScHroeder, J. W. 2012. Interpretating forages analysis. Department of Agriculture. North Dakota State University, U.S. A.

Seegmiller, R. F., and R. D. Ohmart. 1981. Ecological relationships of feral burros and desert bighorn sheep. Wildlife Monographs 78:58.

Shank, C. C. 1982. Age-sex differences in the diets of wintering Rocky Mountain sheep. Ecology 63:627-633.

Sparks, D. R., AND J. C. MelecheK. 1968. Estimating percentage dry weight in diets using a microscopic technique. Journal Range Management 21:264-265.

Strauss, R. E. 1979. Reliability estimates for Ivilev's index, the forage ratio, and a proposed linear index of food selection. Transactions of American Fisheries Society 108:344-352.

Stuth, J. W. 1991. Foraging behavior. Pp. 65-83, in Grazing management. An ecological perspective (Heitschmidt R. K., and J. W. Stuth, eds.). Timber Press, Portland, U. S. A.

Suzukı, R. 2014. Pvclust: Hierarchical Clustering with P-values via multiscale Bootstrap Resampling. R package version 1. 3-2. http://CRAN.R-project.org/package=pvclust.

Tarango, L. A., and P. R. Krausman. 1997. Desert bighorn sheep in Mexico. Desert Bighorn Council Transactions 41:17.

Tarango, L. A., P. R. Krausman, R. Valdez, and R. M. Katinig. 2002. Research observation: Desert bighorn sheep diets in northwestern Sonora, Mexico. Journal of Range Management 55:530-534.

Valdez, R., And P. R. Krausman. 1999. Description, distribution and abundance of mountain sheep in North America. The University of Arizona Press. Tucson, U. S. A.

Submitted: April 14, 2016

Reviewed: July 15, 2016

Accepted: August 30, 2016

Associated editor: Rafael Reyna 
438 THERYA Vol. 7 (3): 423-437 